\title{
MORPHOLOGICAL AND BIOCHEMICAL RESPONSES ASSOCIATED WITH RESISTANCE TO EARIAS VITTELLA FAB. (LEPIDOPTERA: NOCTUIDAE) IN OKRA VARIETIES
}

\author{
Ram Kumar*, PP Singh and Md Abbas Ahmad \\ Department of Entomology, Dr. Rajendra Prasad Central Agricultural University, \\ Pusa, Bihar, 848125, India
}

Keywords: Okra, Screening, Morphological and chemical resistance, Earias vittella

\begin{abstract}
Response of morphological and biochemical traits against okra shoot and fruit borer in different okra varieties were studied. Among the fifteen okra varieties under test Kashi Satdhari was the most superior variety as it showed lowest (2.60) per cent shoot damage followed by D-1-87-5 (3.62\%) and Pusa A-4 $(4.24 \%)$. On the contrary, in Pusa Sawani highest level of shoot infestation (16.23\%) followed by SB-2 (13.74\%) as against Kashi Pragati (check) 10.08 per cent were recorded. Further, okra variety Kashi Satdhari $(7.87 \%)$ showed lowest fruit infestation and was considered as least susceptible variety which was at par with NO-136 (8.77\%), D-1-87-5 (9.12\%) and Kashi Leela (9.38\%). Amongst all the okra varieties evaluated for their susceptibility to fruit infestation, Pusa Sawani and VRO-03 showed relatively higher fruit infestation i.e. 35.17 and 33.41 per cent, respectively and registered as the most inferior varieties against (26.12\%) Kashi Pragati (check). The correlation study between fruit infestation and morphological factors implied that primary branching and trichome length adversely affect the borer infestation. Further, phenol and phosphorus availability in host plant also showed negative effect on shoot and fruit borer infestation.
\end{abstract}

\section{Introduction}

Okra, Abelmoschus esculentus L. (Monech) a major economically important Malvaceous vegetable crops (Mohnasundaram and Sharma 2011) is raised extensively throughout India (Kumar et al. 2017). The yield loss due to insect pests is a major problem in vegetable production and productivity (Halder et al. 2019). Among all the insect pests of okra, shoot and fruit borer, Earias species is one of the major yields reducing constraint (Atwal and Dhaliwal 1997, Balkrishnan et al. 2011, Muthukumaran and Ganeshan 2017). The yield loss due to shoot and fruit borer alone is up to the extent of 3.5 to 90 per cent in different region of the country (Mandal et al. 2006). Insecticides are frequently used by the farmers and this is mainly because of their rapid action against insect pests. With the same cause, demand of chemical insecticide is increasing day by day, even it is environmentally unsafe and has many drawbacks viz. insecticide resistance, pest resurgence, pesticide residue etc (Kadu et al. 2018). Resistant varieties are considered as a noteworthy alternative of insecticide in insect pest management. Plant resistance is an effective tool to combat the insect pest. Host physical characteristics influence the infestation degree (Kamshi and Srinivasan 2008). The richness of herbivore insect's assemblages is strongly influenced by the plants structural diversity i.e. by distribution of plant structures in vertical plane. Besides, it is also affected by plants architectural attributes i.e. by the availability and distribution of plant parts or structure in space above the ground (Brown and Southwood 1987). The defensive (secondary) metabolites can be either constitutive stored as inactive forms phytoanticipins or induced in response to the insect or microbe attack (phytoalexins) War et al. (2012). Considering the above facts, the present study was conducted to identify the antixenotic and antibiotic mechanisms of resistance in different okra varieties against shoot and fruit borer.

*Author for correspondence: <rk440659@gmail.com>. 


\section{Materials and Methods}

Thirteen okra varieties viz. Pusa Makhmali, SB-8, Kashi Lalima, Pusa Sawani, SB-2, VRO03, D-1-87-5, Azad Bhendi-1, NO-136, Kashi Satdhari, Kashi Leela, Pusa-A-4 and Kashi Pragati (susceptible check) were made available by Indian Institute of Vegetable Research, Varanasi and two hybrids, Masina-1 and Ankur-41 were collected from local market. All the varieties collected were used for screening purpose against okra shoot and fruit borer under natural infestation conditions. The site of experimentation was Research Farm of Tirhut College of Agriculture, Dholi, Muzaffarpur, Bihar. The experiment was laid out in RBD with three replications, during kharif 2018 and 2019. Size of the plot was $6 \mathrm{~m}^{2}$ with spacing of $50 \times 20 \mathrm{~cm}$. The material under the experiment was raised as per recommended agronomic practices except pesticide application.

Shoot infestation was calculated on number basis by using the method adopted by Kassi et al. (2017). Fruit infestation was estimated on weight basis by sorting out infested and healthy fruits and weight of infested as well as total harvested fruits were recorded. Further, the extent of per cent fruit damage was worked out on weight basis by using the formula proposed by Anand $e t a l$. 2014. Finally the relative degrees of resistance to key pest i.e. shoot and fruit borer was judged on the basis of shoot and fruit infestation in each variety by adopting the procedure of Kumbhar et al. (1991). The total phenol, flavonoids and tannin in plant samples were estimated by using the procedure of Singleton and Rossi (1965) Quettier et al. (2000) and Attarde et al. (2010), respectively with some modifications. Moreover, total $\mathrm{P}$ in plant samples was determined by vanadomolybdate-phosphoric yellow colour using Calorimetric method Olsen et al. (1954) while, total potassium was determined by using Flame photometer method (Jackson 1973) and expressed in terms of optical density (OD) values.

Morphological characters viz. trichome density on mature fruits and tender leaves (mid vein, side vein and lamina) were counted under binocular microscope by selecting three top leaves each from randomly selected five plants after 60 days after sowing. Trichome length was measured by using an ocular micrometer under stereo-microscope by following the procedure of Ramalho et al. (1984).

Fruit length $(\mathrm{cm})$, fruit width $(\mathrm{cm})$, primary branches per plant and plant height $(\mathrm{cm})$ were evaluated according to distinctiveness Uniformity Stability guidelines descriptors (IPGRI 1991 or UPOV 2006). Upper fruit angle (degree) with respect to plant stem was measured with the help of a protractor for ten fruits in each treatment. Fruit yield per plant (g) was determined by harvesting physiologically mature fruits from ten tagged plants in each treatment and weighed using an electronic balance at each picking and finally average was worked out. Moisture per cent in leaves was determined by taking three samples each of $50 \mathrm{~g}$ leaves from top portions of randomly selected plants of each plot. To assess the number of seeds per fruit, ten mature fruits were plucked randomly from each treatment and carried to the laboratory. A slit was made on the fruit to remove the seed outside and counted manually.

\section{Results and Discussion}

The shoot infestation inflicted by $E$. vittella varied significantly among the okra varieties under test $(\mathrm{P} \leq 0.05)$ Table 1 . Ultimately, the E. vittella infestation preference to shoot varied among the okra varieties which can be ranked from the maximum to minimum as: Pusa Sawani> SB $-2>$ VRO - 03> Ankur - 41> SB - 8> Kashi Pragati > Pusa Makhamali > Masina - 1> Azad Bhindi - 1> Kashi Lalima> Kashi Leela> NO - 136> Pusa-A-4> D-1-87-5> Kashi Satdhari. The okra varieties Kashi Satdhari (2.60\%) showed the lowest shoot infestation followed by D-1-87-5 (3.62\%) and Pusa A-4 (4.24\%). However, among the varieties evaluated, Pusa Sawani showed the highest level of shoot infestation (16.23\%) and found to suffer most, followed by SB-2 (13.74\%) 
as against Kashi Pragati 10.08 per cent. The variation in shoot infestation among the tested varieties might be due to their genetic, nutritional and morphological differences. Balakrishnan et al. (2011) studied the degree of resistance against shoot and fruit borer and recorded nil to 31.92 per cent shoot infestation among different genotypes. Aziz et al. (2012) reported 14.67 to 26.29 with 25.71 per cent in Pusa Sawani which provides good support to the present investigation. Further, Sharma and Singh (2010) observed 4.07 to 15.10 per cent shoot infestation in different varieties/cultivars of okra. According to Singh et al. (2007) the shoot infestation begins in early crop growth stage and damage up to the of 43.99 per cent in okra.

Table 1. Relative performance of different okra varieties against shoot and fruit borer, Earias vittella under open field conditions (pooled mean of kharif 2018 and 2019).

\begin{tabular}{|c|c|c|c|c|c|c|}
\hline \multirow[t]{2}{*}{ Variety } & \multicolumn{3}{|c|}{ Per cent shoot infestation } & \multicolumn{3}{|c|}{ Per cent fruit infestation } \\
\hline & 2018 & 2019 & Pooled & 2018 & 2019 & Pooled \\
\hline \multirow[t]{2}{*}{ Pusa Makhamali } & 11.17 & 7.95 & 9.56 & 28.67 & 25.60 & 27.13 \\
\hline & $(19.50)^{*}$ & $(16.37)$ & $(18.00)$ & (32.33) & $(30.38)$ & $(31.37)$ \\
\hline \multirow[t]{2}{*}{ SB-8 } & 12.67 & 8.29 & 10.48 & 23.43 & 21.97 & 22.70 \\
\hline & $(20.82)$ & $(16.65)$ & $(18.85)$ & (28.94) & (27.93) & $(28.44)$ \\
\hline \multirow[t]{2}{*}{ Kashi Lalima } & 8.34 & 6.35 & 7.35 & 16.84 & 14.75 & 15.79 \\
\hline & $(16.77)$ & (14.59) & $(15.72)$ & (24.17) & (22.57) & $(23.38)$ \\
\hline \multirow[t]{2}{*}{ Pusa Sawani } & 17.26 & 15.20 & 16.23 & 37.68 & 32.65 & 35.17 \\
\hline & $(24.52)$ & $(22.93)$ & $(23.73)$ & $(37.85)$ & $(34.83)$ & $(36.35)$ \\
\hline \multirow[t]{2}{*}{ SB-2 } & 14.75 & 12.73 & 13.74 & 28.26 & 24.30 & 26.28 \\
\hline & $(22.57)$ & (20.89) & (21.74) & $(32.05)$ & $(29.52)$ & $(30.80)$ \\
\hline \multirow[t]{2}{*}{ VRO-03 } & 12.55 & 10.58 & 11.56 & 35.83 & 30.98 & 33.41 \\
\hline & (20.73) & (18.97) & (19.87) & (36.74) & (33.80) & (35.28) \\
\hline \multirow[t]{2}{*}{ D-1-87-5 } & 4.34 & 2.90 & 3.62 & 10.00 & 8.25 & 9.12 \\
\hline & (11.94) & (9.66) & (10.96) & (18.43) & (16.64) & (17.56) \\
\hline \multirow[t]{2}{*}{ Azad Bhindi-1 } & 9.56 & 6.84 & 8.20 & 20.10 & 16.50 & 18.25 \\
\hline & (17.97) & (15.11) & (16.62) & (26.55) & $(23.65)$ & (25.27) \\
\hline \multirow[t]{2}{*}{ NO-136 } & 5.08 & 4.20 & 4.64 & 9.79 & 7.74 & 8.77 \\
\hline & (13.00) & (11.82) & (12.43) & (18.22) & (16.10) & $(17.20)$ \\
\hline \multirow[t]{2}{*}{ Kashi Satdhari } & 2.90 & 2.30 & 2.60 & 8.87 & 6.87 & 7.87 \\
\hline & $(9.78)$ & $(8.72)$ & $(9.27)$ & (17.32) & (15.19) & (16.28) \\
\hline \multirow[t]{2}{*}{ Kashi Leela } & 5.60 & 4.85 & 5.23 & 10.40 & 8.35 & 9.38 \\
\hline & (13.66) & $(12.72)$ & (13.20) & (18.80) & (16.78) & $(17.82)$ \\
\hline \multirow[t]{2}{*}{ Pusa-A-4 } & 4.38 & 4.10 & 4.24 & 19.47 & 17.47 & 18.47 \\
\hline & (12.04) & (11.67) & (11.87) & (26.17) & (24.67) & (25.43) \\
\hline \multirow{2}{*}{$\begin{array}{l}\text { Kashi Pragati } \\
\text { (C) }\end{array}$} & 12.24 & 7.92 & 10.08 & 29.23 & 23.00 & 26.12 \\
\hline & $(20.45)$ & (16.33) & (18.49) & (32.62) & (28.63) & $(30.71)$ \\
\hline \multirow[t]{2}{*}{ Masina-1 } & 10.46 & 7.45 & 8.96 & 19.92 & 17.92 & 18.92 \\
\hline & (18.81) & (15.83) & (17.39) & (26.62) & $(25.02)$ & $(25.75)$ \\
\hline \multirow[t]{2}{*}{ Ankur-41 } & 11.59 & 9.58 & 10.59 & 21.27 & 18.70 & 19.98 \\
\hline & (19.89) & (18.02) & (18.97) & (27.40) & (25.57) & (26.53) \\
\hline $\operatorname{S.Em}( \pm)$ & $(0.68)$ & $(0.57)$ & $(0.39)$ & $(1.29)$ & $(0.71)$ & $(0.73)$ \\
\hline $\mathrm{CD}(\mathrm{P}=0.05)$ & (1.97) & (1.67) & (1.14) & (3.29) & (2.08) & (2.12) \\
\hline $\mathrm{CV}(\%)$ & 12.39 & 11.45 & 8.47 & 13.96 & 8.87 & 9.20 \\
\hline
\end{tabular}

*Figures in parentheses are the values angular transformation. 
The per cent fruit infestation was significantly different among all the varieties of okra under test $(\mathrm{P} \leq 0.05)$ (Table 1). The fruit infestation recorded from different okra varieties ranged from 7.87 to 35.17 per cent. However, among all okra variety screened Kashi Satdhari $(7.87 \%)$ was the best and was with minimum fruit infestation, which was at par with NO-136 (8.77\%), D-1-87-5 $(9.12 \%)$ and Kashi Leela (9.38\%). Further, Pusa Sawani and VRO-03 were got maximum fruit infestation i.e. 35.17 and 33.41 per cent, respectively as against Kashi Pragati 26.12 per cent and found as most preferable host for Earias vitella larva. The remaining varieties illustrated intermediate levels of fruit infestation. The present findings are in accordance with the findings of Sharma and Singh (2010) and Gautam et al. (2013) who reported significant variation in fruit infestation among the tested varieties/genotypes. Halder et al. (2015) assessed the genotypic susceptibility to okra shoot and fruit borer and revealed varied degree of infestation among the genotypes screened. Aziz et al. (2012) also found significant variation in fruit infestation (8.17 to $18.93 \%$ ) among different tested genotypes. The findings are also consistent with the results of Balakrishnan et al. (2011).

All the okra varieties were evaluated for their relative degree of susceptibility to shoot and fruit infestation according to Kumbhar et al. (1991). The nature of okra varieties had changed to shoot and fruit borer reaction when assessed on shoot infestation basis. Thus, there is a need to categorize them separately. The data presented in Table 2 revealed that out of 15 varieties screened, only three varieties viz. Pusa Sawani, SB-2 and VRO-03 were categorized as moderately resistant $(11-<21)$ and the remaining twelve varieties were considered as highly resistant $(1-$ $<11)$ to shoot infestation. However, for fruit infestation, four varieties viz. Kashi Satdhari, NO136, Kashi Leela and D-1-87-5 were found highly resistant $(1-<11 \%)$ to shoot and fruit borer infestation. Dissimilarly, Pusa Sawani and VRO-03 were found to be highly susceptible (>31\%) on the basis of fruit infestation.

Table 2. Categorization of okra varieties on the basis of their relative degree of resistance to shoot and fruit borer (Based on pooled mean of two crop seasons i.e. Kharif 2018 and 2019).

\begin{tabular}{|c|c|c|c|c|}
\hline $\begin{array}{l}\text { Sl. } \\
\text { No. }\end{array}$ & Category & $\begin{array}{l}\text { Per cent } \\
\text { infestation }\end{array}$ & Shoot & Fruit \\
\hline i. & Immune & 0 & Nil & Nil \\
\hline ii. & Highly resistant & $1-<11$ & $\begin{array}{l}\text { Pusa Makhamali, SB-8, Kashi } \\
\text { Pragati, D-1-87-5, NO-136, Kashi } \\
\text { Satdhari, Kashi Leela, Kashi } \\
\text { Lalima, Azad Bhindi-1, Pusa-A-4, } \\
\text { Masina-1 and Ankur-41 }\end{array}$ & $\begin{array}{l}\text { D-1-87-5, NO-136, Kashi } \\
\text { Satdhari, and Kashi Leela }\end{array}$ \\
\hline iii. & $\begin{array}{l}\text { Moderately } \\
\text { resistant }\end{array}$ & $11-<21$ & Pusa Sawani, SB-2 and VRO-03 & $\begin{array}{l}\text { Kashi Lalima, Azad } \\
\text { Bhindi-1, Pusa-A-4, } \\
\text { Masina-1 and Ankur-41 }\end{array}$ \\
\hline iv. & Susceptible & $21-<31$ & Nil & $\begin{array}{l}\text { Pusa Makhamali, SB-8, } \\
\text { SB-2 and Kashi Pragati }\end{array}$ \\
\hline $\mathrm{v}$. & Highly susceptible & $>31$ & Nil & Pusa Sawani and VRO-03 \\
\hline
\end{tabular}

Data of correlation of fruit infestation with morphological characters presented in Fig. 1 clearly indicated that the primary branches $(\mathrm{r}=0.481)$ had positive correlation and significantly affect the fruit infestation. On the contrary, trichome length on fruit $(\mathrm{r}=-0.646)$ had negative and highly significant correlation with fruit infestation. Moreover, other polymorphic characters affect 
the fruit infestation non-significantly. Sharma and Singh (2010) Halder et al. (2015) and Anitha and Karthika (2018) showed negative association between trichome density and length with fruit infestation which lent a good support to the present investigation. On the contrary, Aziz et al. (2012) found non-significantly positive correlation between trichome density on fruit and fruit damage caused by E. vittella, whereas hair density on midrib and hair density on lamina had a positively significant correlation with the fruit infestation on okra. Further, Gautam et al. (2013) also observed positive and non-significant correlation of fruit hair density with fruit infestation. According to Halder et al. (2015) high trichome density might be imparting the physical barrier for the borer rendering their non-preference over the low trichome genotypes. Aziz et al. (2012) reported positive and non-significant relationship between trichome length on fruit, leaf lamina and midrib and fruit damage caused by E. vittella, while the correlation between hair length on side vein and fruit infestation was positive and highly significant. Similar observations were also recorded by Anitha and Karthika (2018) who showed negative association between trichome length and fruit damage and varied from the present results.

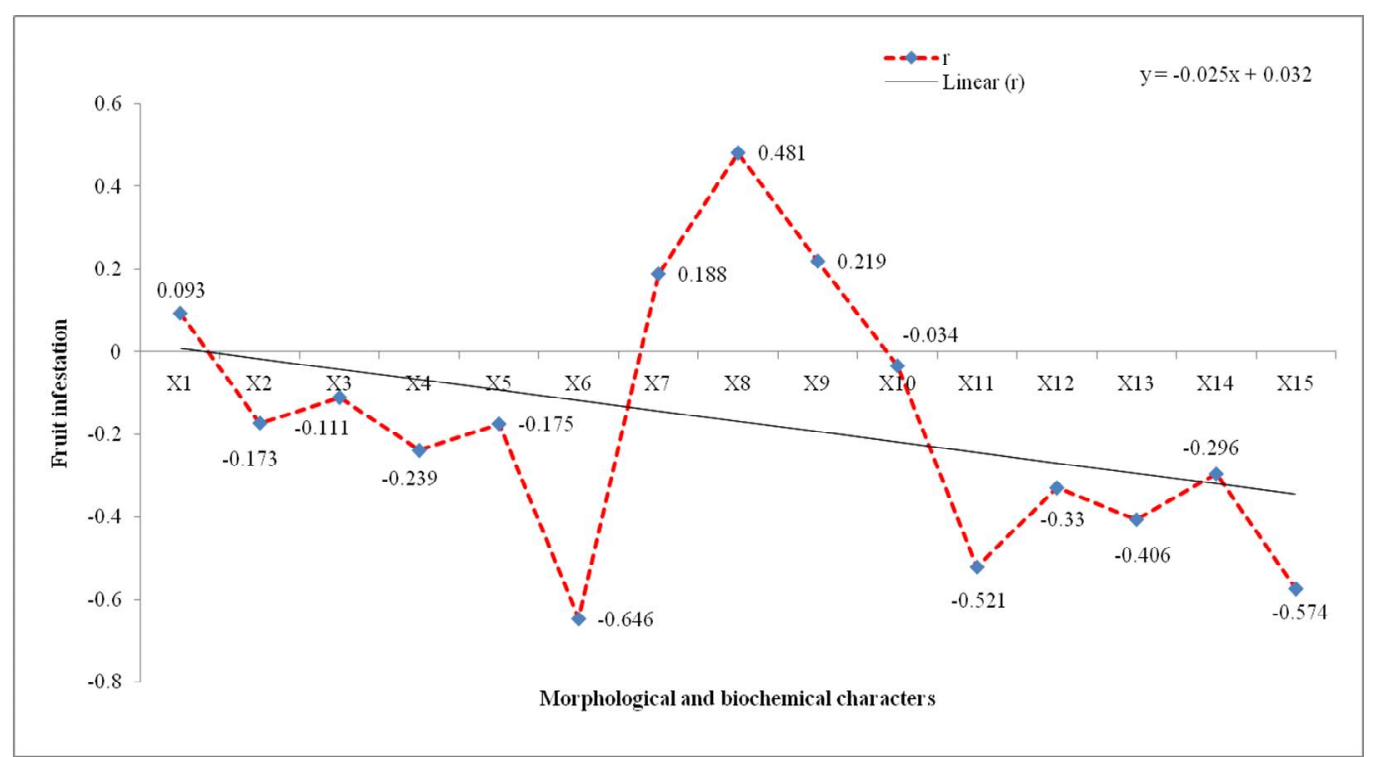

Fig. 1. Correlation of phytomorphometric and biochemical attributes (X) with pests infestation (Y) (Based on pooled mean of two crop seasons i.e. Kharif 2018 and 2019)

[X1 - Fruit angle, X2 - Fruit width, X3 - Fruit length, X4 - Seed/ fruit, X5 - Trichome density (fruit), X6 Trichome length (fruit), X 7 - Plant height, X8 - Primary Branches/ plant, X9 - weight of five fruit/ plant, X10 - Moisture content, X11 - Phenol, X12 - Flavonoid, X13 - Tannin, X14 - Potassium and X15 Phosphorus]

According to Halder and Srinivasan (2005) the correlation between fruit angle and borer infestation was negative and had significant effect on fruit damage. More or less similar results were also recorded by Halder et al. (2015) and Anitha and Karthika (2018) who observed okra varieties having less fruit angle with stem suffered more to shoot and fruit borer attack and thus showed negative correlation with fruit infestation. According to Sharma and Singh (2010) the fruit infestation had positive association with seed per fruit. Further, Gautam et al. (2013) also claimed positive and non-significant correlation of seed per fruit with fruit infestation which provides good support to the present findings. The present findings are in close agreement with the findings of 
Gautam et al. (2013) and Halder et al. (2015) who found negative and significant relationship between fruit width and fruit infestation. The present findings are in line with the findings of Aziz et al. (2012) who stated that fruit length had negative correlation with fruit damage. Halder et al. (2015) suggested that the genotypes with tall plant, dense foliage and bushy appearance favoured more to the okra shoot and fruit borer attack. Furthermore, Strong et al. (1984a) and Denno (1994b) stated that large plants and structurally complex plants often support higher densities of insect herbivores because they provide a great variety of feeding and ovipositional sites, overwintering sites and refuges from natural enemies than do structurally simple plants. According to Balakrishnan and Sreenivasan (2010) the plant height was negatively associated with $E$. vittella infestation. The present results are more or less similar with the findings of Halder et al. (2015) who reported the high fruit weight and high number of fruits per plant in varieties which had high fruit infestation and vice-versa, thus showing positive correlation. In contrast, the report of Aziz et al. (2012) confirmed that the fruit yield per plant had negative correlation with fruit infestation whereas, leaf moisture contents showed no significant effect on fruit infestation.

Data related to correlation of fruit infestation with biochemical factors presented in Table 3, revealed that, among the entire chemical assessed, only phenol $(r=-0.521)$ and phosphorus $(r=-$ 0.574 ) showed negative and significant effect against Earias vittella survival whereas, others affect non-significantly. The findings of Halder et al. (2015) are in close proximity with the present investigation who established negative and non-significant correlation of phenol with okra shoot and fruit borer incidence. Further, Gautam et al. (2013) stated that the phenol and potassium had negative and significant effect on okra shoot and fruit borer. According to Sharma and Singh (2010) the okra varieties had more phenol availability showing resistance to the Earias vittella attack. Similar results were also reported by Jat and Pareek (2003), Halder et al. (2006), Halder and Srinivasan (2007). On the contrary, Aziz et al. (2012) found positive and significant correlation of fruit damage with potassium concentration in plants while phosphorus had positive and highly significant correlation with fruit infestation which varied from the present results.

From the above discussion, it may be concluded that among all the fifteen okra varieties Kashi Satdhari suffered least and showed resistance to okra shoot and fruit borer attack. However, Pusa Sawani seems to appear most susceptible okra variety against Earias vittella. Correlation studies indicate that insect infestation is directly influenced by plant architecture and biochemical factors.

\section{References}

Anand GKS, Sharma RK and Shankarganesh K 2014. Evaluation of bio-efficacy and compatibility of emamectin benzoate with neem based biopesticide against fruit borers of brinjal and okra. Indian J. Agricul. Sci. 84(6): 746-53.

Anitha S and Karthika N 2018. Antixenosis resistance in okra accessions against shoot and fruit borer Earias vittella (Fab.). J. Phytol. 10: 27-32.

Attarde DL, Patil MB, Chaudhari BJ and Pal SC 2010. Estimation of Tannin Content in Some Marketed Harde Churna (Terminalia chebula Retz. Family- Combretaceae). Int. J. Pharma Technol. 2(3): 750-756.

Atwal AS and Dhaliwal GS 1997. Agricultural pests of South Asia and their management. Malhotra Publishing House.

Aziz MA, Hasan MU, Ali A, Suhail A and Sahi ST 2012. Role of different physico-chemical characters of okra as a host plant for preference of Earias spp. Pak. J. Zool. 44(2): 361-369.

Balakrishnan D and Sreenivasan E 2010. Correlation and path analysis studies in okra Abelmoschus esculentus (L.) Moench. Madras Agricul. J. 97(10/12): 326-328.

Balakrishnan D, Sreenivasan E and Radhakrishnan VV 2011. Fruit and shoot borer resistance (Earias vittella Fab.) in okra, Abelmoschus esculentus (L.) Moench. Asian J. Bio Sci. 6(2): 194-197. 
Brown VK and Southwood TRE 1987. Secondary succession: patterns and strategies, in colonization, succession and stability (eds Gray AJ, Crawley MJ and Edwards PJ). Blackwell Scientific Publication, Oxford, 315-337.

Denno RF 1994b. Influence of habitat structure on the abundance and diversity of planthoppers. Pages 140159 in RF Denno and TJ Perfect, editors. Planthoppers: Their Ecology and Management. New York: Chapman and Hall.

Gautam HK, Singh NN, Singh C and Rai AB 2013. Morphological and biochemical characters in fruits against okra shoot and fruit borer (Earias vittella F.). Indian J. Entomol. 75(3): 189-193.

Halder J and Srinivasan S 2007. Biochemical basis of resistance to spotted pod borer, Maruca vitrata (Geyer) in urd bean. Ann. Plant Protec. Sci. 15(2): 287-90.

Halder J and Srinivasan S 2005. Morphological basis of resistance to spotted pod borer, Maruca vitrata (Geyer) in urd bean. Shaspa 12(2): 102-105.

Halder J, Kushwaha D, Deb D and Rai AB 2019. Abundance of distribution of sucking pests complex of okra in relation to meteorological parameters. J. Agrometeorol. 21(2): 227-229.

Halder J, Sanwal SK, Rai AK, Rai AB, Singh B and Singh BK 2015. Role of physico-morphic and biochemical characters of different okra genotypes in relation to population of okra shoot and fruit borer, Earias vittella (Noctuidae: Lepidoptera). Indian J. Agricul. Sci. 85(2): 278-282.

Halder J, Srinivasan S and Muralikrishna T 2006. Role of various biophysical factors on distribution and abundance of to spotted pod borer, Maruca vitrata (Geyer) in mung bean. Ann. Plant Protec. Sci. 15(1): 49-51.

IPGRI 1991. International Crop Network Series. Report of an International Workshop on Okra Genetic Resources. International Board for Plant Genetic Resources, Rome.

Jackson ML 1973. Soil chemical analysis, Prentice Hall of India Ltd. New Delhi, pp. 183-204.

Jat KL and Pareek BL 2003. Biophysical and biochemical factors of resistance in brinjal against Leucinodes orbonalis (Guen). Indian Journal of Entomology 65(2): 252-258.

Kadu RV, Kulkarni SR, Patil PV and Patil SK 2018. Screening of different genotypes of okra (Abelmoschus esculentus) against leaf hopper, Amarasca biguttula biguttula Ishida. J. Entomol. Zool. Stud. 6(5): 1960-1963.

Kamakshi N and Srinivasan S 2008. Influence of certain biophysical factors on incidence of pod borer complex in selected genotypes of field bean. Ann. Plant Protec. Sci. 16(2): 407-9.

Kassi AK, Javed H, Naeem M and Mukhtar T 2017. Screening of genotypes of okra against American bollworm on the basis of shoot infestation. J. Entomol. Zool. Stud. 5(4): 850-852.

Kumar S, Singh VK, Kumar A and Chandra N 2017. Bioefficacy of Coragen against Shoot and Fruit Borer, Earias vittella (Fab.) in Okra. Int. J. Curr. Microbiol. Appl. Sci, 6(10): 1021-1027.

Kumbhar TT, Dumber A and Kokate AS 1991. Studies on the varietal resistance in okra, Abelmoschus esculentus L. (Moench) to shoot and fruit borer, Earias spp. Maharashtra J. Horticult. 5: 78-82.

Mandal SK, Sah SB and Gupta SC 2006. Screening of okra cultivars against Earias vittella. Ann. Plant Protec. Sci. 14: 471-472.

Mohanasundaram A and Sharma RK 2011. Abundance of pest complex of okra in relation to abiotic and biotic factors. Ann. Plant Protec. Sci. 19(2): 286-290.

Muthukumaran N and Ganesan P 2017. Antixenosis resistance in okra and their hybrid derivatives against shoot and fruit borer Earias vittella (Fab.). J. Entomol. Zool. Stud. 5(4): 1884-1887.

Olsen SR, Cole CV, Watanable FS and Dean LA 1954. Estimation of available phosphorus in soil by extraction with sodium bicarbonate. USDA circular, 939, pp. 19-23.

Quettier DC, Gressier B, Vasseur J, Dine T, Brunet C, Luyckx MC, Cayin JC, Bailleul F and Trotin F 2000. Phenolic compounds and antioxidant activities of buck wheat (Fagopyrum esculentum Moench) hulls and flour. Ethnopharmacology 72: 35-42.

Ramalho FS, Parrot WL, Jenkins JN and McCarty Jr JC 1984. Effects of cotton leaf trichomes on the mobility of newly hatched tobacco budworms. J. Econ. Entomol. 77: 619-621. 
Sharma BN and Singh S 2010. Biophysical and biochemical factors of resistance in okra against shoot and fruit borer. Indian J. Entomol. 72(3): 212-6.

Singh SK, Singh AK and Singh HM 2007. Relative resistance of okra germplasm to shoot and fruit borer, Earias vittella Fab. under field conditions. J. Appl. Zool. Res. 18(2): 121-123.

Singleton VL and Rossi JA 1965. Colorimetry of total phenolics with phosphomolybdic-phosphotungstic acid reagents. American J. Enol. Viticul. 16: 144-158.

Strong DR, Lawton JH and Southwood TRE 1984a. Insects on Plants: Community Patterns and Mechanisms. Cambridge, MA: Harvard University Press.

UPOV 2006. Plant Variety Protection Gazette and Newsletter. International Union for the Protection of New Varieties of Plants.

War AR, Paulraj MG, Ahmad T, Buhroo AA, Hussain H, Ignacimuthu S and Sharma HC 2012. Mechanisms of plant defense against insect herbivores. Plant Signaling \& Behavior. 7(10): 1306-1320.

(Manuscript received on 16 May, 2021; revised on 25 July, 2021) 